\title{
Gas Chromatography-Mass Spectrometry Analysis and $\alpha$-Glucosidase Inhibitory Activity of $n$-Hexane Extract of Bilajang Bulu (Merremia Vitifolia) Leaves
}

\author{
Candra Yulius Tahya ${ }^{*}$, Karnelasatri² \\ ${ }^{1}$ Chemistry Education Department, Faculty of Education, Universitas Pelita Harapan, \\ Tangerang, Indonesia \\ 2D3 Pharmacy Department, Faculty of Health Sciences, Universitas Pelita Harapan, \\ Tangerang, Indonesia \\ *E-mail: candra.tahya@uph.edu
}

Received: 12 October 2021; Accepted: 7 December 2021; Published: 15 December 2021

\begin{abstract}
One of the most effective treatments for diabetes mellitus is to inhibit $\alpha$-glucosidase, which inhibits glucose absorption by the epithelium membrane of the small intestine. In South Sulawesi, Indonesia, Merremia vitifolia is used as a traditional medicine for the treatment of diabetes. The aims of this study are to (1) assess the extract's ability to inhibit $\alpha$ - glucosidase and (2) identify volatile organic compounds in n-hexane of Merremia vitifolia extract. Extraction was conducted by maceration. The inhibitory activity of quercetin towards $\alpha$-glucosidase has the $I C_{50}=2.53 \pm 0.16 \mu \mathrm{g} / \mathrm{mL}$, and by $n$ Hexane extract of Merremia vitifolia leaves has the $I_{50}=14.4 \pm 1.52 \mu \mathrm{g} / \mathrm{mL}$. Then, $n$-Hexane extract of Merremia vitifolia leaves has strong a-glucosidase inhibitory activity. The compounds that have been identified based on Gas Chromatography-Mass Spectrometry (GC-MS) analysis with similarity index $\geq 89 \%$ which are caryophyllene (0.94\%), (E)- $\beta$-famesene (4.72\%), neophytadiene (9.78\%), phytol (65.94\%), 9,12,15-octadecatrienoic acid (6.71\%), 1,5-cyclodecadiene (6.76\%), squalene (4.48\%), stigmasterol (4.08\%), $\gamma$-sitosterol (10.20\%), Serratol (23.12\%), vitamin E (2.78\%) and lup20(29)-en-3-one (21.04\%). Based on a literature study, the presence of phytol, neophytadiene, $\beta$-caryophyllene, stigmasterol, $\gamma$-sitosterol, and lup-20(29)-en-3-one have contributed to the strong $\alpha$-glucosidase inhibitory activity of $n$-Hexane extract of Merremia vitifolia leaves.
\end{abstract}

Keywords: GC-MS; Inhibition of $\alpha$-glucosidase; Merremia vitifolia; Phytol

\section{Introduction}

One of the chronic and serious human metabolic disorders is diabetes mellitus. The disease was characterized by a high concentration of plasma glucose, which led to major complications such as cardiovascular disease, diabetic neuropathy, and retinopathy. The number of patients increases every year all around the world, especially in low-middle income countries, including Indonesia (Kumar et al., 2011; Munasaroh et al., 2018). One of the most effective treatments for diabetes mellitus is to inhibit $\alpha$-glucosidase, which inhibits glucose absorption by the epithelium membrane of the small intestine (Kumar et al., 2011). The enzyme catalyzes the hydrolytic cleavage of oligosaccharide into monosaccharide, i.e. glucose to be absorbed, so by the inhibition of

162

Copyright ( 2021 WJC | ISSN 2621-5985 (online) | ISSN 2549-385X (print)

Volume 4, Issue 2, 2021 
the enzyme, overall absorption of glucose by the small intestine could be delayed, lowering the postprandial blood glucose level, and assisting to avoid of late diabetic complications (Proença et al., 2017). One of the potentials candidates for diabetic drug development is plant secondary metabolites.

Merremia vitifolia (M. vitifolia) is one of the plants in Convolvulaceae family that is widely grown in Southeast Asian region, including Indonesia (GBIF Secretariat, 2019). This plant in Indonesia is called Akar Bulu. It is known as Bilajang Bulu in South Sulawesi, and its leaves are used as a traditional medicine to treat diabetics (Hasanah et al., 2019). The water extract of the plant has antibacterial activity against Staphylococcus aureus and contains flavonoid (Hasanah et al., 2020).

M. vitifolia leaves had been evaluated for its antioxidant, thrombolytic, antiarthritic and anti-nociceptive potential (Akter et al., 2021), but in this research, $n$-Hexane was used to extract the non-polar compound from $M$. vitifolia leaves, and to identify the volatile organic compound by using Gas Chromatography-Mass Spectrometry (GCMS) and to evaluate the extract activity to inhibit $\alpha$-glucosidase.

\section{Research Methods}

\section{Materials and Tools}

Identification of $M$. vitifolia (Burm. F) Hallier f. (family Convolvulaceae) plant was conducted by the Research Center of Biology, Indonesian Institute of Sciences (LIPI) based on the morphology characteristic of the plant. Fresh leaves of $M$. vitifolia were collected from the forest around Pelita Harapan University. Around $500 \mathrm{~g}$ of leaves were collected, cleansed with water, let dry at room temperature, and cut into small pieces. Then it was dried for 36 hours at $80^{\circ} \mathrm{C}$ in the oven. The dried pieces of leaves were refined into powder with a blender. As much as 83.69 grams of dried powder were collected. The solvent that was used for maseration was $n$ Hexane (Analytical Grade, Merck). For column chromatography, sea sands, cotton, ethyl acetate (Analytical Grade, Merck), TLC 60 aluminium plat F254 (Merck), and Silica gel $60(0.2-0.5 \mathrm{~mm})$ were used for column chromatography.

The phosphate buffer was made by dissolving $3.59 \mathrm{~g}$ of $\mathrm{Na}_{2} \mathrm{HPO}_{4}$ in $100 \mathrm{~mL}$ of distilled water (solution $\mathrm{A}$ ) and $1.39 \mathrm{~g}$ of $\mathrm{NaH}_{2} \mathrm{PO}_{4}$ in $100 \mathrm{~mL}$ of distilled water (solution B). Solution A is added with solution $B$ until it reaches pH 7.0 then stirs it with distilled water so that the volume becomes $200 \mathrm{~mL}$. Enzyme for inhibition test was $\alpha$ glucosidase Type I (EC 3.2.1.20) of Saccharomyces cerevisiae and its synthetic substrate, p-nitrophenyl- $\alpha$-Dglucopyranoside (p-NPG) were purchased from Wako. A maximum of $1.0 \mathrm{mg}$ of $\alpha$ glucosidase (62 units / $\mathrm{mg}$ ) was dissolved in $100 \mathrm{ml}$ of phosphate buffer $\mathrm{pH} 7.0$ containing $200 \mathrm{mg}$ of bovine serum albumin. For testing enzyme stock 10x diluted with phosphate buffer pH 7.0 (equivalent to 0.062 units). pNitrophenyl- $\alpha$-D-glucopyranoside $150.65 \mathrm{mg}$ was dissolved in $25 \mathrm{~mL}$ of $\mathrm{pH}$ 7,0 phosphate buffer. The substrate solution was diluted to the $\mathrm{Na}_{2} \mathrm{CO}_{3} 0.2 \mathrm{M}$ solution is used to stop the enzymatic reactions.

UV light was used to detect spot in TLC. Rotary evaporator (Heidolph) was used for solvent evaporation, GC-MS (Agilent 7890B with MSD 5977 A) was used to identify the volatile organic compounds in the extract based on NIST17 library.

\section{Procedure}

\section{Maseration}

Around $83.69 \mathrm{~g}$ of dried powder of M. vitifolia leaves were separated into two $(41.0 \mathrm{~g}$ on each) and put them into two Erlenmeyer flasks $1000 \mathrm{~mL}$ and added $410 \mathrm{~mL}$ of $n$ Hexane into each flask, cover the top of flask with plastic shield and aluminium foil, and strirred with magnetic stirer for 6 hours at room temperature. Filtered the dissolved extract with filter paper and evaporated the solvent with rotavapour. Collected and weighted the extract, and stored it in dark at room temperature. 


\section{Inhibition of $\alpha$-glucosidase assay}

Inhibition of $\alpha$-glucosidase assay was conducted base on the report of Munasaroh, Tamat, \& Dewi (2018). As much as 4,0 mg of sample was dissolved in $500 \mu \mathrm{L}$ of DMSO as a main solution, then diluted with DMSO in order to obtain a varied concentration of the sample at $50 ; 25 ; 12.5 ; 6.25 \mu \mathrm{g} / \mathrm{mL}$. Quercetin 4,0 $\mathrm{mg}$ as a reference substance was dissolved into $500 \mu \mathrm{L}$ of DMSO to obtain a varied concentration of the quercetin at $20 ; 10 ; 5 ; 2.5$ $\mu \mathrm{g} / \mathrm{mL}$.

Around $10 \mu \mathrm{L}$ of a varied concentration of sample dissolved in DMSO were prepared and 5 min pre-incubated with $250 \mu \mathrm{L}$ of enzyme solution, and $490 \mu \mathrm{L}$ of phosphate buffer $0.1 \mathrm{M}(\mathrm{pH} 7.0)$ at $37^{\circ} \mathrm{C}$. And roughly $5 \mu \mathrm{L}$ of various concentration of quercetin dissolved in DMSO were prepared and $5 \mathrm{~min}$ pre-incubated with $250 \mu \mathrm{L}$ of enzyme solution, and $495 \mu \mathrm{L}$ of phosphate buffer $0.1 \mathrm{M}(\mathrm{pH} 7.0)$ at $37^{\circ} \mathrm{C}$. The addition of $250 \mu \mathrm{L}$ p-NPG $5 \mathrm{mM}$ was to initiate the reaction. After 15 minutes of reaction incubation, $1 \mathrm{~mL}$ of $\mathrm{Na}_{2} \mathrm{CO}_{3} 0.1 \mathrm{M}$ was added to stop the reaction. $\alpha$-Glucosidase activity was measured by GC-MS at $400 \mathrm{~nm}$ as the concentration of p-nitrophenol (pNP) released. The blank was made with phospate buffer instead of enzyme and had the right background absorbance. Equation 1 was used to compute the inhibitory activity:

$\%$ Inhibition $=\frac{\text { Absorbance of control reaction }}{\text { Absorbance in the presence of sample }} \times 100 \%$

The $\mathrm{IC}_{50}$ is calculated by using linier regression eq. Where $\mathrm{x}$ axis is sample concentration and y axis is \% inhibition.

\section{Column chromatography}

The eluent used for column chromatography was determined based on the separation of spots with TLC silica gel. The best separation was observed by using 4:1 ratio of $n$-Hexane and ethyl acetate. Column tools set were prepared. About $25 \mathrm{~g}$ of silica gel 60 (0.2-0.5 mm) was put into column with eluent of $4: 1$ ratio of $n$-Hexane : ethyl acetate, respectively. About $0.1 \mathrm{~g}$ of $M$. vitifolia leaves extract was disolved into eluent and put into column for separation.

Separation was conducted with 8 times adding of $20 \mathrm{~mL}$ eluent $4: 1$ ratio of $n$ Hexane: ethyl acetate, and 3 times of adding $20 \mathrm{~mL}$ eluent of 8:1 ratio of $n$-Hexane : ethyl acetate. There are 20 fractions that has been collected, for further TLC silica gel evaluation. Based on the TLC spots, fraction 1 and 2 with no clear spot observed. Fraction 3 - 9 have more than one spot in TLC, and fraction 9-18 also have more than one spot and shows similar TLC pattern, fraction 19 - 20, no clear spots. Because of the pattern similarity of the spots in the TCL layer, researchers decided to mix together fraction 1 - 9 into fraction of ' $F 1$ Merremia', and fraction $9-20$ into fraction 'F2 Merremia' for further GC-MS analysis after removal of solvents.

Operation conditions for gas chromatography was automatic sample injection with $1 \mu \mathrm{L}$ injection volume at $250^{\circ} \mathrm{C}$, and helium as carrier gas, $\mathrm{CH}_{2} \mathrm{Cl}_{2}$ was used as solvent. The initial temperature $40^{\circ} \mathrm{C}$ hold for $1 \mathrm{~min}$, ramp at $10^{\circ} \mathrm{C} / \mathrm{min}$ to $300^{\circ} \mathrm{C}$ for $4 \mathrm{~min}$. Single Quadrupole MS method was used with scan time segment start from mass 30.00 to 600.00. Scan speed $781[\mathrm{~N}=3] \mathrm{u} / \mathrm{s}$, scan frequency $1.3 / \mathrm{sec}$, cycle time $754 \mathrm{~ms}$ and step size $0.1 \mathrm{~m} / \mathrm{z}$.

\section{Result and Discussion}

\section{The n-Hexane extract of M. vitifolia leaves}

The weight of $n$-Hexane extract resulted from the maseration of $83.69 \mathrm{~g} M$. vitifolia was $0.182 \mathrm{~g}(0.203 \%$ yield $)$. The yield is smaller than ethanol extract $(2.61 \%)$ reported by Hasanah, et al (Hasanah et al., 2019). The color of the extract was chart reuse with the strong unique odor. The fraction of 'F1 Merremia' has yellow-orange color, while the 'F2 Merremia' fraction has green color. 


\section{Inhibition of $\alpha$-glucosidase results}

The inhibition of $\alpha$-glucosidase assay by $n$-hexane extract of $M$. vitifolia leaf was conducted with quercetin as positive control. Table 3 shows $\alpha$-Glucosidase inhibitory activity by quercetin has $\mathrm{IC}_{50}=2.53 \pm 0.16$ $\mu \mathrm{g} / \mathrm{mL}$, and Table 4 shows $\alpha$-glucosidase inhibitory activity by n-hexane extract has $\mathrm{IC}_{50}=14.4 \pm 1.52 \mu \mathrm{g} / \mathrm{mL}$. Quercetin shows stronger inhibition activity than $n$-Hexane extract. But still, $n$-Hexane extract of $M$. vitifolia leaves has strong $\alpha$-glucosidase inhibitory activity.

The IC $_{50}$ value of $\alpha$-glucosidase inhibitory activity of $M$. vitifolia $n$-Hexane extract is stronger compared to several other plants extract such as $n$-Hexane extracts of Garcinia fruticose Lauterb $\left(\mathrm{IC}_{50}=643.20\right.$ $\mu \mathrm{g} / \mathrm{mL}$ ) (Zahratunnisa et al., 2017), the extract of Quercus gilva Blume ( $\mathrm{IC}_{50}=110.0$ $\mu \mathrm{g} / \mathrm{mL}$ ), Xylosoma congestum Merr. ( IC $_{50}=$ $182.3 \mu \mathrm{g} / \mathrm{mL}$ ), Quercus dentata Thunb ( IC $_{50}=$ $42.2 \mu \mathrm{g} / \mathrm{mL}$ ), Quercus glauca Thunb ( IC $_{50}=$ $44.7 \mu \mathrm{g} / \mathrm{mL}$ ) and Podocarpus macrophyllus var maki $\left(\mathrm{IC}_{50}=45.2 \mu \mathrm{g} / \mathrm{mL}\right.$ ) (Indrianingsih et al., 2015). The tropical plants that had $\alpha$ glucosidase inhibitor activity within an IC $_{50}>200 \mu \mathrm{g} / \mathrm{mL}$, mean weak inhibitory activity (Indrianingsih et al., 2015).

\section{GC-MS analysis}

The GC-MS analysis was conducted to the fraction of ' $F$ 1 Merremia' and 'F2 Merremia'. Separation of the $n$-Hexane extract into both fractions before the GC-MS analysis was meant to avoid peaks overlapping and baseline noise in gas chromatography. There are 10 volatile organic compounds (Table 1) that have been identified by GC-MS in fraction 'F1 Merremia' (Figure 1) based on the NIST17 library with a similarity index (SI) higher than 89\%. Similarity index less than $89 \%$ was not considered. Phytol (48.79\%) was the most abundance compound in 'F1 Merremia' fraction. Meanwhile, in the fraction ' $F$ 2 Merremia', there 4 volatile organic compounds (Table 2) that have been identified by GC-MS based on NIST17 library with SI is more than 91\% (Figure 2). The most abundance compound in 'F2 Merremia' fraction was Serratol (23.12\%).

The GC-MS analysis reveals various compounds in $n$-hexane extract of $M$. vitifolia which several of them have biological activities. Neophytadiene, phytol and Lup20(29)-en-3-one were presence in both F1 and F2 Merremia fractions. Total of percentage abundance neophytadiene, phytol and lup-20(29)-en-3-one in both fractions were $9.78 \%, \quad 65.94 \%$ and $21.04 \%$, respectively. Phytol is the most abundance chemical, and $\beta$-Caryophyllene is the least abundance chemicals that were detected by GC-MS in $n$-Hexane extract of M. vitifolia (Figure 3). The high quantity of phytol in M. vitifolia was originally documented here, to the best of the researcher's knowledge. Phytol has been found in Rhaphidophora pinnata by several different researchers (27.64\%) (Tualeka et al., 2018), Lantana camara (4.0\%) and L. radula (29.2\%) (Passos et al., 2012), Argemone mexicana (8.03\%) (Gawade \& Farooqui, 2017), Ipomoea Caprae and Merremia Umbellata (Ganjir et al., 2013), and Justicia gendarussa (Phatangare et al., 2017).

Phytol, an acyclic diterpene alcohol, is a precursor for the biosynthesis of chlorophyll, vitamin $\mathrm{E}$, and vitamin $\mathrm{K}$, as well as having antioxidant and antinociceptive properties (Santos et al., 2013). Phytol was shown to be cytotoxic agent against seven tumor cells using the MTT assay in vitro with highest activity to the breast adenocarcinoma MCF-7 (Pejin et al., 2014). Phytol have demonstrated anti-inflammatory, antioxidant, antinociceptive, anxiolytic, metabolism-modulatin, immune-modulating, and antimicrobial effects (Islam et al., 2018). Phytol and its derivative compounds are known as potent immune adjuvant (Chowdhury \& Ghosh, 2012). 
Phytol and neophytadiene also has been reported to have the $\alpha$-glucosidase inhibition activity (Gawade \& Farooqui, 2017). The molecular docking analysis depicted that phytol had the best docking binding energy for inhibition of enzyme $\alpha$ - glucosidase, compare to neophytadiene and $\beta$-Caryophyllene (Oso \& Olaoye, 2020).

Table 1. Chemical composition of 'F1 Merremia' fraction

\begin{tabular}{lccc}
\hline \multicolumn{1}{c}{ Compound } & $\begin{array}{c}\text { Retention } \\
\text { Time } \\
\text { (minute) }\end{array}$ & $\begin{array}{c}\text { \% } \\
\text { Abundance }\end{array}$ & $\begin{array}{c}\text { Similarity } \\
\text { Index }\end{array}$ \\
\hline Caryophyllene & 12.697 & 0.94 & 99 \\
(E)- $\beta$-Famesene & 13.079 & 4.72 & 95 \\
Neophytadiene & 17.366 & 2.10 & 99 \\
Phytol & 20.035 & 48.79 & 99 \\
9,12,15-Octadecatrienoic acid & 20.307 & 6.71 & 99 \\
1,5-Cyclodecadiene & 20.433 & 6.76 & 89 \\
Squalene & 25.674 & 4.48 & 99 \\
Stigmasterol & 28.940 & 4.08 & 99 \\
$\gamma$-Sitosterol & 29.482 & 10.20 & 99 \\
Lup-20(29)-en-3-one & 30.112 & 3.01 & 99 \\
\hline
\end{tabular}

Table 2. Chemical composition of 'F2 Merremia' fraction

\begin{tabular}{lccc}
\hline \multicolumn{1}{c}{ Compound } & $\begin{array}{c}\text { Retention } \\
\text { Time } \\
\text { (minute) }\end{array}$ & $\begin{array}{c}\text { \% } \\
\text { Abundance }\end{array}$ & $\begin{array}{c}\text { Similarity } \\
\text { Index }\end{array}$ \\
\hline Neophytadiene & 17.346 & 7.68 & 99 \\
Phytol & 20.068 & 17.15 & 91 \\
Serratol & 20.383 & 23.12 & 99 \\
Vitamin E & 27.768 & 2.78 & 99 \\
Lup-20(29)-en-3-one & 30.024 & 18.03 & 99 \\
\hline
\end{tabular}




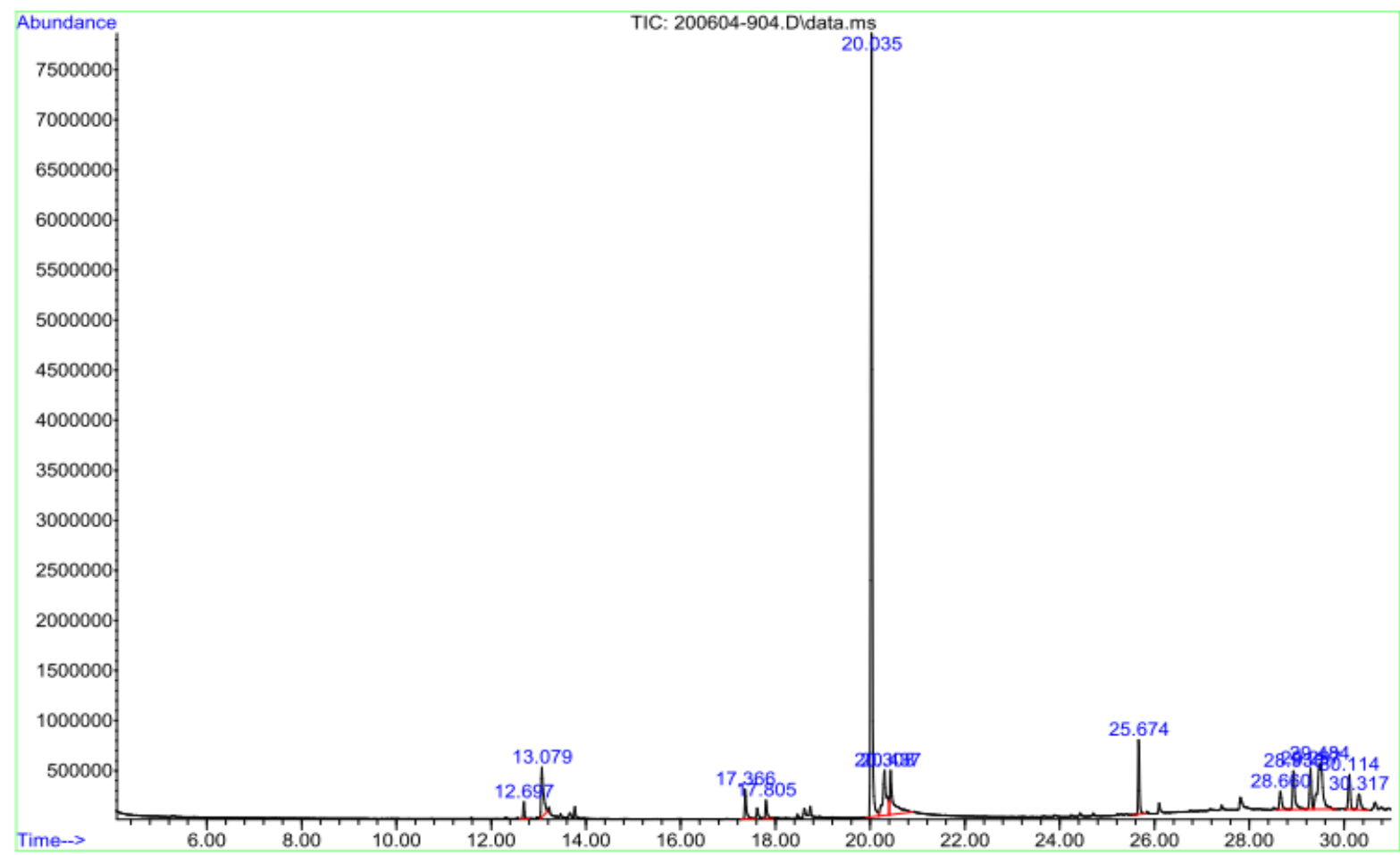

Figure 1. GC-MS Chromatogram of 'F1 Merremia' fraction

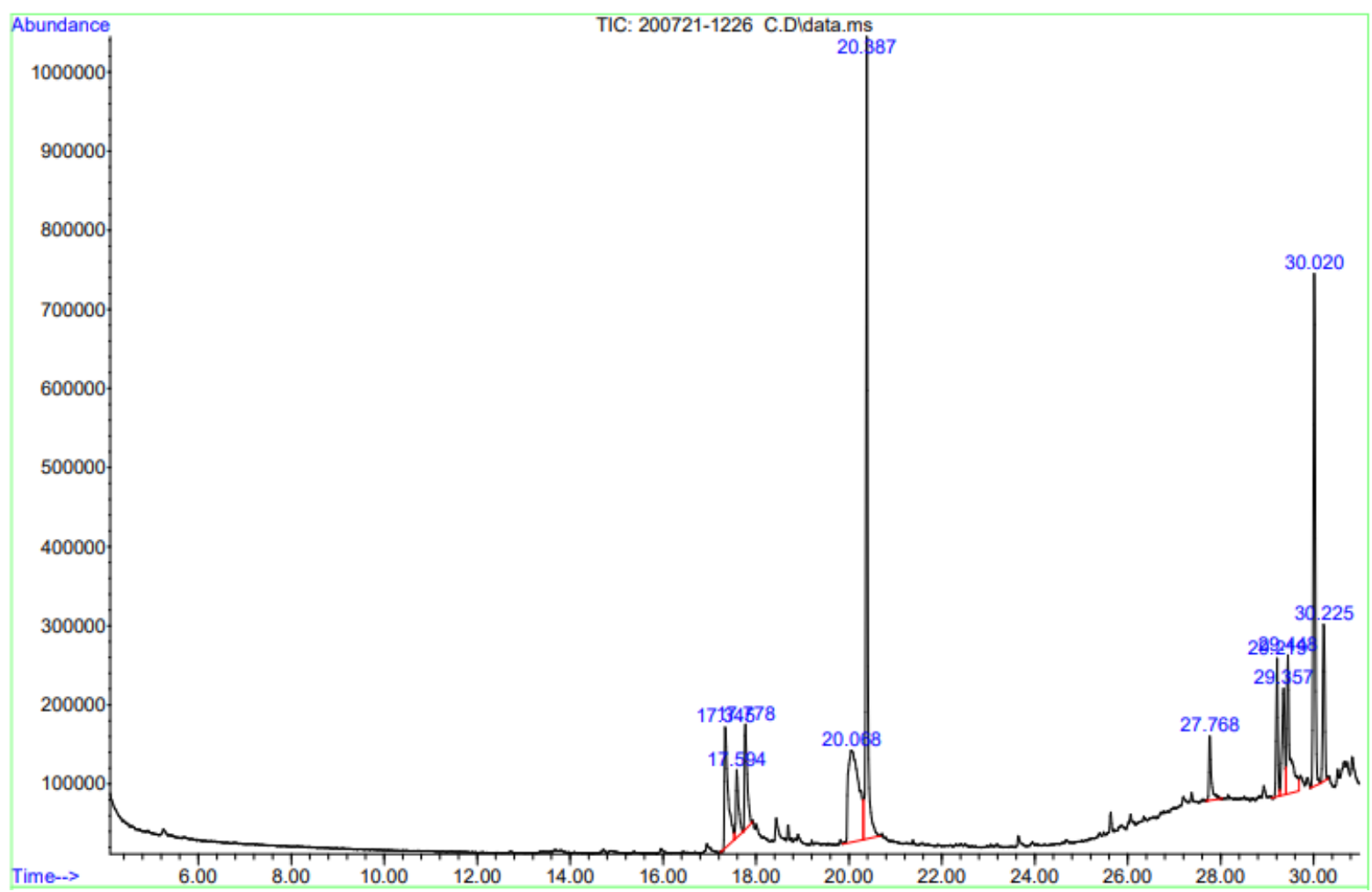

Figure 2. GC-MS Chromatogram of 'F2 Merremia' fraction 


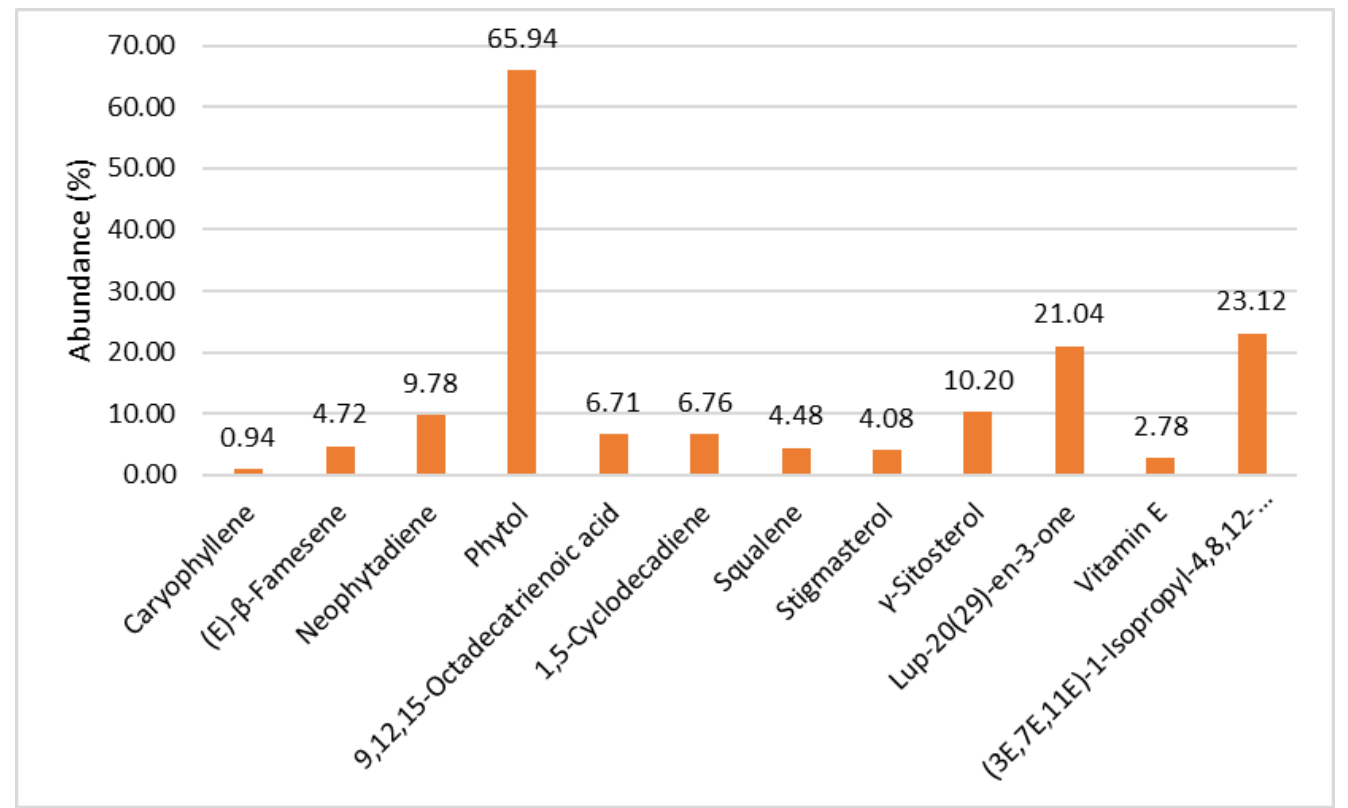

Figure 3. Chemical abundance (\%) of $n$-Hexane extract of $M$. vitifolia leaves based on GC-MS.

Table 3. $\alpha$-Glucosidase inhibition by quercetin

\begin{tabular}{llllll}
\hline \multirow{2}{*}{ Sample name } & \multicolumn{4}{l}{ \% Inhibition in $\mu \mathrm{g} / \mathrm{mL}$} & \multirow{2}{*}{} \\
\cline { 2 - 6 } & 2.5 & 5 & 10 & 20 & IC $_{50}(\mu \mathrm{g} / \mathrm{mL})$ \\
\hline Quercetin & $49.93 \pm 1.54$ & $66.54 \pm 3.84$ & $73.64 \pm 3.26$ & $99.48 \pm 0.61$ & $2.53 \pm 0.16$ \\
\hline
\end{tabular}

Table 4. $\alpha$-Glucosidase inhibition by $n$-hexane extract of $M$. vitifolia leaves

\begin{tabular}{llllll}
\hline \multirow{2}{*}{ Sample name } & \multicolumn{4}{l}{$\%$ Inhibition in $\mu \mathrm{g} / \mathrm{mL}$} & \multirow{2}{*}{ IC } \\
\cline { 2 - 5 } & 6.25 & 12.5 & 25 & 50 & \\
\hline $\begin{array}{l}\text { n-hexane } \\
\text { extract }\end{array}$ & $12.583 \pm 6.5$ & $46.81 \pm 7.07$ & $77.12 \pm 0.03$ & $96.69 \pm 0.78$ & $14.4 \pm 1.52$ \\
\hline
\end{tabular}

Docking binding energy of phytol, neophytadiene, $\quad \beta$-Caryophyllene, and acarbose toward $\alpha$-glucosidase were -6.8, $5.3,-6.2$ and $-9.8 \mathrm{kcal} / \mathrm{mol}$, respectively (Oso \& Olaoye, 2020). Similar to the report of Nokhala et al.,(2020) based on molecular docking results showed that phytol, vitamin E, stigmasterol, and quercetin have $\alpha$ glucosidase inhibitory effect, and stigmasterol has lowest bonding energy.

Phytol and stigmasterol also were reported to responsible for $\alpha$-glucosidase inhibitory activity (Murugesu et al., 2018).
Stigmasterol has shown $\alpha$-glucosidase inhibitory effect and significant antidiabetic activity in streptozotocin-nicotinamide induced diabetic mice (Kumar et al., 2013). Another sterol molecule, $\gamma$-sitosterol is an epimer of $\beta$-sitosterol, has antihyperglycemic activity by increasing insulin secretion in response to glucose (Sirikhansaeng et al., 2017). High concentration of stigmasterol dan $\gamma$-sitosterol were observed in Parinarium glaberimum Hassk (Tahya et al., 2020) which is known traditionally in Moluccas to treat diabetic patients. 
$\beta$-Caryophyllene has been reported to be directly beneficial to treat diabetes mellitus (Kumawat \& Kaur, 2019) and inflammation of colon (Colitis) (Bento et al., 2011). $\beta$-Caryophyllene was found to be therapeutic in the following diseases: Alzheimer (Hu et al., 2017), epilepsy (Oliveira et al., 2016), osteoblast dysfunction (Shan et al., 2017), and cancer (Tabana et al., 2015). Lup-20(29)-en-3-one, belongs to pentacyclic lupane-type triterpenes is the oxidized form of lupeol. Lupeol itself is well known to have many beneficial pharmacological activities including anti-inflammatory, antihyperglycemic, antioxidant, antidyslipidemic and anti-mutagenic effects (Tsai et al., 2016). Because of high structural similarity to Lupeol, the Lup-20(29)-en-3-one could be a multi-target compound to explore various pharmacological potency with many potential targeting proteins including $\alpha$ glucosidase. Several other pentacyclic lupane-type triterpenes have been reported to show $\alpha$-glucosidase inhibitory activity stronger than acarbose (Yin et al., 2014). Another activities of lup-20(29)-en-3-one are to increase the melanin content of the tested cell without cytotoxicity (Yin et al., 2014) and an active compound against trypomastigotes of Trypanosoma cruzi (Polanco-Hernández et al., 2012).

The second major component of $n$ Hexane extract of $M$. vitifolia leaves is (3E,7E,11E)-1-isopropyl-4,8,12-

trimethylcyclotetradeca-3,7,11-trienol also called as serratol or cembrenol. This organic compound belongs to the class of cembrane diterpenoids. Serratol compound has been reported as antiprotozoal compound (Schmidt et al., 2011). Serratol was tested for in vitro activity against 4 protozoan pathogens in human, which are Trypanosoma brucei rhodesiense (East African Human Trypanosomiasis, sleeping sickness), T. cruzi (Chagas' disease), Leishmania donovani (KalaAzar), and Plasmodium falciparum (Tropical Malaria). They found that this compound is active against $T$. brucei and P. falciparum. These activities were 10- to 15-fold higher than its cytotoxicity against rat skeletal myoblasts (Schmidt et al., 2011). In researcher best knowledge, this report is the first to identify serratol in M. vitifolia. These open the other potential to isolate serratol for further research in Malaria drugs development in Indonesia.

Based on the literatures reported, the presence of phytol, neophytadiene, $\beta$ caryophyllene, stigmasterol, $\gamma$-sitosterol, and lup-20(29)-en-3-one were responsible to the strong $\alpha$-glucosidase inhibitory activity of $n$ Hexane extract of $M$. vitifolia leaf.

\section{Conclusion}

The amount of $\alpha$-Glucosidase inhibitory activity by quercetin has the $\mathrm{IC}_{50}=2.53 \pm 0.16$ $\mu \mathrm{g} / \mathrm{mL}$, and by $n$-Hexane extract of M. vitifolia leaves has the $\mathrm{IC}_{50}=14.4 \pm 1.52 \mu \mathrm{g} / \mathrm{mL}$. $n$ Hexane extract of $M$. vitifolia leaves has strong $\alpha$-glucosidase inhibitory activity. M. vitifolia leaves could be good potential target for antidiabetic drugs development. There are 12 compounds that have been indentified based on GC-MS analysis of $n$-Hexane extract of $M$. vitifolia leaves with similarity index more than $89 \%$. Caryophyllene, (E)- $\beta$-famesene, neophytadiene, phytol, 9,12,15octadecatrienoic acid, 1,5-cyclodecadiene, squalene, stigmasterol, $\gamma$-sitosterol, Serratol, vitamin E and lup-20(29)-en-3-one. Phytol is the most abundance chemical, and $\beta$ Caryophyllene is the least abundance chemicals that were detected.

\section{Acknowledgement}

This work was financially supported by LPPM Universitas Pelita Harapan (UPH), with registration number P-036/FIP/I/2020 and P-005-FIP/II/2021. Thanks to LPPM UPH and Fakultas Ilmu Pendidikan UPH.

\section{Reference}

Akter, S., Jahan, I., Khatun, M. R., Khan, M. F., Arshad, L., Jakaria, M., Haque, M. A. (2021). Pharmacological insights into Merremia vitifolia (Burm.f.) Hallier f. leaf for its antioxidant, thrombolytic, anti-arthritic and anti-nociceptive potential. Biosci Rep, 41 (1): BSR20203022. doi: 
https://doi.org/10.1042/BSR2020302 2

Bento, A. F., Claudino, R. F., Dutra, R. C., Marcon, R., \& Calixto, J. B. (2011). Omega-3 fatty acid-derived mediators 17(R)-hydroxy docosahexaenoic acid, aspirin-triggered resolvin D1 and resolvin D2 prevent experimental colitis in mice. Journal of Immunology (Baltimore, Md. : 1950), 187(4), 19571969.

https://doi.org/10.4049/jimmunol.11 01305

Chowdhury, R. R., \& Ghosh, S. K. (2012). Phytolderived novel isoprenoid immunostimulants. Frontiers in Immunology, 3(MAR), 1-11. https://doi.org/10.3389/fimmu.2012. 00049

Ganjir, M., Behera, D. R., \& Bhatnagar, S. (2013). Phytochemical Analysis, Cytotoxic And Antioxidant Potential of Ipomoea Pes Caprae(L)R.Br And Merremia Umbellata(L.)H. Hallier. Phytochemical Analysis, Cytotoxic And Antioxidant Potential of Ipomoea Pes Caprae (L)R.Br And Merremia Umbellata(L.)H. Hallier., 2(5), 80-83.

Gawade, B., \& Farooqui, M. (2017). AlphaAmylase Inhibitory Assay of Argemone mexicana L. Leaves. Available Online Www.Jocpr.Com Journal of Chemical and Pharmaceutical Research, 9(12), 25-29. www.jocpr.com

GBIF Secretariat. (2019). M. vitifolia (Burm.fil.) Hall.fil. https://doi.org/https://doi.org/10.15 468/39omei

Hasanah, E., Ayu, N. K., \& Puspita, D. (2020). Activity Test of Leaf Ethanol Extract Bilajang Bulu Merremia Vitifolia Against Staphylococcus Aureus Bacteria. Al-Kimia, 8(1), 29-35. https://doi.org/10.24252/alkimiav8i1.6368
Hasanah, E., Ayu, N. K., Puspita, D., \& Sukarti, S. (2019). Analysis of Flavaniod Content From Extract Ethanol Bilajang Bulu Leaf (Merremia vitifolia). Jurnal Akta Kimia Indonesia (Indonesia Chimica Acta), 12(1), 73. https://doi.org/10.20956/ica.v12i1.64 56

Hu, Y., Zeng, Z., Wang, B., \& Guo, S. (2017). Trans-caryophyllene inhibits amyloid $\beta$ (A $\beta) \quad$ oligomer-induced neuroinflammation in BV-2 microglial cells. International Immunopharmacology, 51, 91-98. https://doi.org/10.1016/j.intimp.2017 .07 .009

Indrianingsih, A. W., Tachibana, S., \& Itoh, K. (2015). In Vitro Evaluation of Antioxidant and $\alpha$-Glucosidase Inhibitory Assay of Several Tropical and Subtropical Plants. Procedia Environmental Sciences, 28(SustaiN 2014), 639-648. https://doi.org/10.1016/j.proenv.201 5.07.075

Islam, M. T., Ali, E. S., Uddin, S. J., Shaw, S., Islam, M. A., Ahmed, M. I., Chandra Shill, M., Karmakar, U. K., Yarla, N. S., Khan, I. N., Billah, M. M., Pieczynska, M. D., Zengin, G., Malainer, C., Nicoletti, F., Gulei, D., Berindan-Neagoe, I., Apostolov, A., Banach, M., ... Atanasov, A. G. (2018). Phytol: A review of biomedical activities. Food and Chemical Toxicology: An International Journal Published for the British Industrial Biological Research Association, 121, 82-94. https://doi.org/10.1016/j.fct.2018.08. 032

Kumar, S., Kumar, V., \& Prakash, O. (2013). Enzymes Inhibition and Antidiabetic Effect of Isolated Constituents from Dillenia indica. BioMed Research International, 2013, 1-7.

Kumar, S., Narwal, S., Kumar, V., \& Prakash, O. (2011). $\alpha$-glucosidase inhibitors from 
plants: A natural approach to treat diabetes. Pharmacognosy Reviews, 5(9), 19-29. https://doi.org/10.4103/09737847.79096

Kumawat, V. S., \& Kaur, G. (2019). Therapeutic potential of cannabinoid receptor 2 in the treatment of diabetes mellitus and its complications. European Journal of Pharmacology, 862, 172628.

https://doi.org/https://doi.org/10.10 16/j.ejphar.2019.172628

Munasaroh, S., Tamat, S. R., \& Dewi, R. T. (2018). Isolation and identification of aglucosidase inhibitor from aspergillus terreus F38. Indonesian Journal of Pharmacy, 29(2), 74-79. https://doi.org/10.14499/indonesianj pharm29iss2pp74

Murugesu, S., Ibrahim, Z., Ahmed, Q., Yusoff, N. N., Uzir, B., Perumal, V., Abas, F., \& Saari, K. (2018). Clinacanthus nutans Lindau Leaves by Gas Metabolomics and Molecular Docking Simulation. Molecules, 23(2402), 1-21. https://doi.org/10.3390/molecules23 092402

Nokhala, A., Siddiqui, M. J., Ahmed, Q. U., Safwan, M., Bustamam, A., \& Zakaria, Z. A. (2020). Investigation of $\alpha$ Glucosidase Inhibitory Metabolites from Tetracera scandens Leaves by GC - MS Metabolite Profiling and Docking Studies. Biomolecules, 10(287), 1-17.

Oliveira, C. C. de, Oliveira, C. V. de, Grigoletto, J., Ribeiro, L. R., Funck, V. R., Grauncke, A. C. B., Souza, T. L. de, Souto, N. S., Furian, A. F., Menezes, I. R. A., \& Oliveira, M. S. (2016). Anticonvulsant activity of $\beta$-caryophyllene against pentylenetetrazol-induced seizures. Epilepsy and Behavior, 56, 26-31. https://doi.org/10.1016/j.yebeh.2015. 12.040

Oso, B. J., \& Olaoye, I. F. (2020). Comparative in vitro studies of antiglycemic potentials and molecular docking of
Ageratum conyzoides L. and Phyllanthus amarus L. methanolic extracts. SN Applied Sciences, 2(4), 113. https://doi.org/10.1007/s42452020-2275-5

Passos, J. L., Almeida Barbosa, L. C., Demuner, A. J., Alvarenga, E. S., Da Silva, C. M., \& Barreto, R. W. (2012). Chemical characterization of volatile compounds of lantana camara l. and l. radula sw. and their antifungal activity. Molecules, $17(10)$ 11447-11455. https://doi.org/10.3390/molecules17 1011447

Pejin, B., Kojić, V., \& Bogdanovic, G. (2014). An insight into the cytotoxic activity of phytol at in vitro conditions. Natural Product Research, 28, 1-4. https://doi.org/10.1080/14786419.20 14.921686

Phatangare, N. D., Deshmukh, K. K., Murade, V. D., Naikwadi, P. H., Hase, D. P., Chavhan, M. J., \& Velis, H. E. (2017). Isolation and Characterization of $\beta$-Sitosterol from Justicia gendarussa burm. F.-An AntiInflammatory Compound. International Journal of Pharmacognosy and Phytochemical Research, 9(09), 864872. https://doi.org/10.25258/phyto.v9i09 .10317

Polanco-Hernández, G., Escalante-Erosa, F., García-Sosa, K., Chan-Bacab, M. J., Sagua-Franco, H., González, J., OsorioRodríguez, L., \& Peña-Rodríguez, L. M. (2012). Metabolites from the leaf extract of Serjania yucatanensis with trypanocidal activity against Trypanosoma cruzi. Parasitology Research, 111(1), 451-455. https://doi.org/10.1007/s00436-0122861-6

Proença, C., Freitas, M., Ribeiro, D., Oliveira, E. F. T., Sousa, J. L. C., Tomé, S. M., Ramos, M. J., Silva, A. M. S., Fernandes, P. A., \& Fernandes, E. (2017). $\alpha$-Glucosidase inhibition by flavonoids: an in vitro and 
in silico structure-activity relationship study. Journal of Enzyme Inhibition and Medicinal Chemistry, 32(1), 1216-1228. https://doi.org/10.1080/14756366.20 17.1368503

Santos, C. C. de M. P., Salvadori, M. S., Mota, V. G., Costa, L. M., de Almeida, A. A. C., de Oliveira, G. A. L., Costa, J. P., de Sousa, D. P., de Freitas, R. M., \& de Almeida, R. N. (2013). Antinociceptive and Antioxidant Activities of Phytol In Vivo and In Vitro Models. Neuroscience Journal, 2013, $\quad 949452$. https://doi.org/10.1155/2013/94945 2

Schmidt, T. J., Kaiser, M., \& Brun, R. (2011). Complete structural assignment of serratol, a cembrane-type diterpene from Boswellia serrata, and evaluation of its antiprotozoal activity. In Planta medica (Vol. 77, Issue 8, pp. 849-850). https://doi.org/10.1055/s-00301250612

Shan, J., Chen, L., \& Lu, K. (2017). Protective effects of trans-caryophyllene on maintaining osteoblast function. IUBMB Life, $\quad$ 69(1), 22-29. https://doi.org/10.1002/iub.1584

Sirikhansaeng, P., Tanee, T., Sudmoon, R., \& Chaveerach, A. (2017). Major Phytochemical as $\gamma$-Sitosterol Disclosing and Toxicity Testing in Lagerstroemia Species. Evidence-Based Complementary and Alternative Medicine, 2017, 7209851. https://doi.org/10.1155/2017/72098 51

Tabana, Y., Dahham, S., Tabana, Y., Iqbal, M. A., Ahamed, M. B. K., Ezzat, M. O., Abdul Majid, A. S., \& Abdul Majid, A. M. S. (2015). The Anticancer, Antioxidant and Antimicrobial Properties of the
Sesquiterpene $\beta$-Caryophyllene from the Essential Oil of Aquilaria crassna. https://doi.org/10.13140/RG.2.1.3843 .9523

Tahya, C. Y., Tiwery, E., Monaten, M. G., \& Lumbantoruan, T. K. J. (2020). Identifikasi Fitosterol dengan Kromatografi Gas - Spektrometer Massa pada Ekstrak Kloroform Biji Buah Atung ( Parinarium Glaberimum Hassk). 4(1), 14-20.

https://doi.org/10.17977/um0260v4i 12020 p014

Tsai, F. S., Lin, L. W., \& Wu, C. R. (2016). Lupeol and its role in chronic diseases. In Advances in Experimental Medicine and Biology (Vol. 929, pp. 145-175). Springer New York LLC. https://doi.org/10.1007/978-3-31941342-6_7

Tualeka, A., Mapanawang, A. L., Petrus, H. C., \& Gambe, A. (2018). Idetification of Phytol Compounds Contained in The Methanol Extract of Dragon Tail Leaves. International Journal of Health Medicine and Current Research, 3(03), 999-1003. https://doi.org/10.22301/IJHMCR.252 8-3189.999

Yin, Z., Zhang, W., Feng, F., Zhang, Y., \& Kang, W. (2014). $\alpha$-Glucosidase inhibitors isolated from medicinal plants. Food Science and Human Wellness, 3(3), 136174.

https://doi.org/https://doi.org/10.10 16/j.fshw.2014.11.003

Zahratunnisa, N., Elya, B., \& Noviani, A. (2017). Inhibition of Alpha-Glucosidase and antioxidant test of stem bark extracts of garcinia fruticosa lauterb. Pharmacognosy Journal, 9(2), 273-275. https://doi.org/10.5530/pj.2017.2.46 